\title{
The Political Aspects of the Establishment of the Planning and Budgeting Policy for The Directorate of Occupational and Sports Health of the Ministry of Health
}

\author{
*Ben Fauzi Ramadhan, **Hasbullah Thabrany, **Dumilah Ayuningtyas \\ * Health Policies and Health Laws Division, Department for Health Policy Administration, Faculty of Public Health \\ ** Department Health Administration and Policy, Faculty of Public Health Universitas Indonesia
}

Email: ben.fauzi@ui.ac.id

\begin{abstract}
The process to establish a planning and budgeting policy in the Directorate for Occupational and Sports Health is very dynamic and it fluctuates according to the goals and priorities of the policy. This research aims to ascertain how far the political aspects influences the establishment process. This research was a qualitative research accomllished through in-depth interviews with related parties. The framework used the planning and budgeting systems model and process/cycle. Results of this research indicated that politics played a major role in the policy establishment process in conflicts, cooperation, and negotiations when setting the size and allocation of the budget and the targets aimed. The main points in the process are the priorities of the program, the fiscal capacity of the nation, and the results of the previous year's evaluation. We recommend that the human resources of the directorate are equipped abilities to advocate the importance of the occupational and sports health program..
\end{abstract}

Keywords: policy, politics, planning, budgeting

\begin{abstract}
Abstrak. Proses penetapan kebijakan perencanaan dan penganggaran pada Direktorat Kesehatan Kerja dan Olahraga sangat dinamis dan bergerak sesuai dengan arah kebijakan dan prioritas. Tujuan penelitian ini yaitu untuk mendapatkan fakta sejauh mana aspek politik ikut berperan dalam penetapan kebijakan perencanaan dan anggaran. Penelitian ini menggunakan metode kualitatif dengan melakukan wawancara mendalam terhadap pihak-pihak yang terlibat. Hasil penelitian menunjukan bahwa aspek politik paling kental terjadi pada tahapan proses penetapan kebijakan terutama saat terjadi konflik, kerjasama, negosiasi dalam penetapan besaran alokasi anggaran dan target yang disusun. Penelitian ini merekomendasikan untuk memperkuat SDM direktorat kesehatan kerja dan olahraga dalam hal kemampuan untuk melakukan advokasi mengenai pentingnya program kesehatan kerja dan olahraga.
\end{abstract}

Kata kunci: kebijakan, politik, perencanaan, penganggaran

\section{INTRODUCTION}

Each year the budget for the health sector increases. However, compared to the total national budget and expenditure (APBN) it only reached 2-3\% (Seputar APBN, 2011-2015). Placing Indonesia at the second lowest rank. Only in 2016 the budget for the health sector reached $5 \%$ or about Rp 104.8 Billion, according to the Global Health Expenditure published by the World Health Organization (WHO dalam Saputra, 2014). The budgeting process has one basic problem, which is the limited resources, both human resources and funding (Abdullah, 2004). The related parties at the executive and legislative levels conducts a bargaining process to set the budget, at the public sector, budgeting is a bargaining process between executives and executive and executive and legislative (Abdullah, 2004).

The political aspect plays a major role in the health sector, while the health sector also influences political rulings (Kickbusch, 2015). The definition of politics used herein is the proves of making and taking decisions collectively which involves selection, negotiation, and the issuing of laws o policies, not what a politician or a political party does (Mackenbach, 2014). The Directorate of Occupational and Sports Health (Dit Kesjaor) as one of the II echelon units of the Directorate General of Public Health (Ditjen Kesmas) based on the Minister of Health Decree (permenkes) no. $64 / 2015$, has a strategic role in supporting the programs of the Ditjen Kesmas. This is also supported by the 237.64 million people living and 121.19 million workforce in Indonesia (BPS, 2015). Of the 121.19 million, 114 million (47.9\%) are currently working. 45.6 million (37\%) works in the formal sector and 68 million (63\%) works in the informal sector (BPS, 2015). Considering the large population, especially the workforce, the Dit Kesjaor should be supported with the suitable budget. In 2016, the budget resceived by Dit. Kesjaor was Rp 156.5 billion, excluding the salary and operational costs to support their main duties and 
functions.

Policymaking in the health sector, including those for planning and budgeting, is influenced by the environment, all the social, political, economical, historical factors, and other factors as well (Ayuningtyas, 2008). The components, process, and allocation of resources, actors, and dominion are factors that influence the policymaking system (Ayuningtyas, 2008).

Various facts, theories, and research results indicated that political aspects are found and influences the planning and budgeting process directly and indirectly (Marhaeni dan Herawati 2008). Based on those facts and issues, we were interested to discover the political aspects that influcnes the planning and budgeting process at the Dit Kesjaor.

\section{METHOD}

This was a qualitative research that used the case study approach to describe the political aspects of the planning and budgeting policymaking of the Dit Kesjaor in detail and comprehensively. The framework used the systems model approach developed by Easton [7] and the planning and budgeting process/cycle stated in permenkes No.7/ 2014.

The data sources used were informants involved in the planning and budgeting process of the Dit Kesjaor, they are the members of the Dit Kesjaor, the Sesditjen Kesmas, the Planning and Budgeting Bureau (Rorenggar) of the Ministry of Health, the Inspectorate General of the Ministry of Health, the Directorate General for Budgeting (DJA) of the Ministry of Finance (Kemenkeu), the Public Health and Nutrition Directorate of the Bappenas, and the IX Commission of the DPR RI. Data was also obtained from reviewing the planning and budgeting documents of the Dit Kesjaor.

The main instrument of this research was the researchers (Moleong, 2007). Other aids were a semistructurized questionanrie for probing in-depth interviews and recording devices for the in-depth interviews. The data review was obtained by studying the planning and budgeting data and documents of the Dit Kesjaor, such as DIPA, RPJMN 2015-2019, Renstra, Renja K/L, and RKAKL.

\section{RESULT AND DISSCUSSION}

\section{The Profile of the Directorate of Occupational and Sports Health}

According to permenkes No. 64/2015 on the organization and work structure of the ministry of health, the Dit Kesjaor is one of the II echelon work units under the Directorate General of Public Health, the ministry of health. The Dit Kesjaor is led by a director and is tasked with formulating and implementing the policies, norms, standards, procedures, and criteria; providing technical guidance and supervision; also providing monitoring, evaluating, and reporting for the occupational and sports health sector according what is stated in the laws.

\section{1-2016 Budget Profile of the Directorate of Occupational and Sports Health}

The Dit Kesjaor receives funds from the central and regional office or through the deconcentration mechanism. The following is the budgeting trend of the Dit Kesjaor:

Table 1. 2011-2016 Budget Allocation of the Directorate of Occupational and Sports

\begin{tabular}{cc}
\hline Year & Allocation (in million rupiah) \\
\hline 2011 & 35,400 \\
2012 & 31,520 \\
2013 & 53,690 \\
2014 & 48,700 \\
2015 & 83,100 \\
2016 & 156,500 \\
\hline
\end{tabular}

\section{Results of the 2016 Planning and Budgeting Document Study}

Based on the 2016 planning and budgeting documents study, which comprised of the performance architecture and information (ADIK), work plan documents, RKP documents, CHR/CHP documents, and the DIPA Dit Kesjaor, the planning and budgeting process for 2016 was:

1. In the ADIK Dit Kesjaor documents, the Dit Kesjaor calculates what is required to obtain the target, which was Rp 200 billion.

2. Renja k/l of the Dit Kesjaor is based on the required Dit Kesjaor budget, which was Rp 200 billion.

3. Based on the indicated pagu, the President established a government work plan through the Perpres No. 60/2015 to include the mother and child health improvement plans into the Dit Keasjaor plans with Rp 200 billion allotted.

4. According to the work plan and budget documents of the Dit Kesjaor, the fixed budget pagu was Rp 176 billion at the central and the deconcentrated budget. Some of the funds were allocated to other activities that are more prioritized by the Dirjen Kesmas and the Ministry of Health, such as for supplement funding (PBI) for the JKN program. The program is prioritized by the President, because it is included in the governmental quick wins programs.

5. According to the DIPA documents and the budget set by the Dirjen Kesmas, Rp 156.5 billion was allocated. The amount was reduced because there were more programs that needed funding and the 
budget was limited. So the priority progams that has the largest impact received more funding. Which program is prioritized is set by the Dit Kesjaor, the Ministry of Health, and the Rorenggar. The Dit KGM bappenas that has the blueprints for the national health sector development is also involved in synchronization and adjustments. This produced an agreement on which program is a priority.

\section{Informant Characteristics}

There were 9 informants involved in this research, from within and without of the ministry. The informants were from various positions, from directors to staff, depending on what document is needed. The age range of the informant was between 27-55 years old and most have worked for over 10 years in the planning and budgeting sector. This is to obtain the necessary information.

\section{Resources}

The input components in this research is the group of elements necessary to create a system, in this case, a planning and budgeting system. The input components involved in this research was human resources, time, and funding. All the human resources in this research was capable of producing results, which are planning and budgeting policies for the directorate, although some parts still needs to be strengthened.

As to the time component, based on the field interviews, we discovered that generally the directorate follows the cycle set by the regulations. Although there might be some deviations, which was caused by deadlocks during the budgeting process, as stated by one informant:

“...it happened in 2013.. the discussions were deadlocked at the DPR.. hmm.. so our DIPA was given a star..." (IF-9)

According to the informants, the funding to support the planning and budgeting activities for parties involved in the process was adequate. Each party involved, including the Dit Kesjaor, allocated funds to facilitate the coordination meetings and travel costs.

The planning and budgeting process of the government has one basic problem, which is limited resources, particularly human resources (Abdullah, 2004). When human resources becomes a problem, the available people may become vulnerable to interfering parties.

The allowable time for planning and budgeting is technically regulated by permenkes no. 7/2014. The planning process is a revolving cycle that does not stop from planning to monitoring to evaluation. However, sometimes there are delays, which creates a time pressure. Many things might cause this, one of them are deadlocks in dicussing what progams that should be prioritized. This exhausts more time until an agreement is reached.

Funding is a multiuse input, but unavailable funding does not stops the planned activities or programs (Hasanbasri, 2007). Planning and budgeting is a routine duty of the Dit Kesjaor, therefore it is prioritized and receives adequate funding each year.

\section{Planning and Budgeting Policymaking Process at the Directorate of Occupational and Sports Health}

The most crucial stage in the planning and budgeting process is the policymaking process. This process is regulated by Permenkes No.7/2014 on organizing plans and budges for the health sector. For the Dit Kesjaor, the Permenkes separates the planning and budgeting process into three stages. Each stage involves various internal parties of the Ministry of Health, this comprises of the Dit Kesjaor, Sesditjen Kesmas, Itjen, and Rorenggar, and the external parties, the DJA, Dit KGM Bappenas, and the IX Commission of the DPR. The process of conflicts, negotiations, and influencing produces an agreed policy.

According to several informants, the indicative pagu is the the amount provided to the Dit Kesjaor after an agreement is reached. Taking into consideration the prioritized and nonprioritized programs, the previous year's ability of the Dit Kesjaor to absorb the funds and realize the targets, and other assumed funds such as the national income and source of funding.

“...the target budget is agreed upon, other priorities that has not received funding, this will be suggested in future budgets, we will review it, the negotiation has already begin then. Um... then the agreed upon target, then um... the budget allocated... sort of like that..." (IF-6)

After the indicative pagu is set, the next stage is setting the budgeted pagu, where, according to the information that we received, all planned expenses must be detailed based on the indicative pagu and the agreement. Then the budget pagu is compiled by the ministry of finance into a presidential financial note that is included into the planned APBN (RAPBN) that is conveyed to the DPR. It is during this stage that many changes, therefore the budget for Dit Kesjaor also changes. This is to accommodate higher priority programs and activities.

"...if there is a mission for PBI for the JKN program, we prioritize that first... then the rest is distributed, automatically the amount for other things is less..." (IF-8) 
The next stage is budget allocation pagu, which is the last stage. This is a follow-up of the previous stage that has accounted for the various considerations ans assumptions and non-governmental parties (DPR) and the end product is the Daftar Isian Pelaksanaan Anggaran (Implemented Budget List or DIPA). We found that the size of the budget after this stae is smaller than at the budget pagu stage and it is after the agreement is reached. Although size of the reduction is not significant.

“....actually it isn't that much different than the budget pagu, so it was called the definitive pagu, now it is the allocated budget pagu, there isn't much deviation. No significant increases or decreases..." (IF-3)

Table 2. Percentage of Decrease from the Indicative Pagu to the Allocated Budget Pagu of the Dit Kesjaor Budget in 2001-2016.

\begin{tabular}{rrrr}
\hline Year & $\begin{array}{c}\text { Indicative Pagu } \\
\text { (Mill. Rp) }\end{array}$ & $\begin{array}{c}\text { Allocated (Mill. } \\
\text { Rp) }\end{array}$ & \% Decrease \\
\hline 2011 & 43.300 & 35.400 & - \\
2012 & 50.250 & 31.520 & 11.2 \\
2013 & 56.200 & 53.690 & 3.6 \\
2014 & 85.200 & 48.700 & 3.1 \\
2015 & 200.000 & 83.100 & 2.5 \\
2016 & & 156.500 & 22.0 \\
\hline
\end{tabular}

We discovered that there is a decreasing trend between the indicative pagu and the allocated budget pagu, albeit insignificant, with the exception of 2016 that reached $22 \%$. This decrease was caused by the limited funds, and prioritized programs are given more funding. An X increase of funds in one program would automatically cause an $\mathrm{X}$ decrease in another program, because the total funds are the same or even less.

\section{Planning and Budgeting Policymaking of the Directorate of Occupational and Sports Health}

The final stage after the planning and budgeting policy is set determines the pagu. The internal parties, which are the director and the directorate general must agree to the programs and budget set by the Dit Kesjaor. The planning and budgeting bureau must determine that the programs planned complies with the policy from the ministry. APIP determines that the work plan and the budget complies with the regulations and the correct accounting principles. The bappenas determines that the programs will support the national development plan and the ministry of finance must ensure that the finances can satisfy the required funds for the activities planned.

The policy is a product of a series of key interactions during the policymaking process where the interests of various actors, dominions, resources, and elits interact and bargains. During the process, they have come to an agreement. The size of the budget is a manifestation of the political power of each party in maintaining their stability and interests (Ayuningtyas, 2008).

The Political Aspects that Influences the Planning and Budgeting Policy Making
The political aspects of policy making begins at the input stage and it produces the DIPA

“...the politics within the Directorate of Occupational and Sports Health is a process that influences each other, which starts at the beginning of the process... umm from when the indicative was compiles, the first was determining the targets that would, um, be reached by the directorate, and then an agreement between, um, several parties that are related with the budget planning of the Directorate of Occupational and Sports Health..." (IF-6)

Budgeting politics is a description of strategies which various participants in budgeting use to further their aims (Wildavsky, 1992). Therefore, the budgeting process is extremely influenced by the public expenditure allocation, public planning and budgeting is more political than technical (Norton dan Elson, 2002). Many parties with their own point of views and interests are involved.

Many dynamics are involved in the budgeting politics, each actor influences the direction of the budgeting policy (Wahyu, 2011). Actors are a group of people that have their individual or group preferences. The related actors from the executive and legislature are involved in a bargaining process to determine the budgeting policy.

\section{Budgeting Politics and Health Politics in Various Countries}

According to Bradley and Cammett (2012) there is a positive relationship between the individual political activities with the probability of access to healthcare (Chen dan Cammet, 2014). An odds ratio of 4.0 was found when comparing individuals with higher political activities with more passive political activities. They also concluded that individuals with higher political activities have access to better healthcare. Political activities are where the individual chooses to participate in politica activities through a political party.

Navarro, et al (2006) found that the political ideology of a country influences its public indicators. They found that there is an empirical relationship between politics and policiees, where political parties with egalitarian views tends to implement policies in a centralized way. The centralized policies are aimed to reduce the injustices that influences the public health aspects, such as infant mortality rate and life expectancy.

According to Andersen, et al (2010), the factors that prolongs the discussions on state budgeting In America was that there was no major party that controls both the executive and legislative. This lack can also be interpreted as the majority of the political parties are 
opposing. Another thing that might prolongate it is that there was no majority in the state parliament, therefore various actors and groups endeavor to conserve their own interests.

Obstacles in the Planning and Budgeting Policy Making at the Directorate of Occupational and Sports Health. The most common obstacle found in the planning and budgeting process in the lack of strategic roadmap. The second most common problem is the tight deadlines. Although there is a set cycle, many events and issues would change it. And coordination betweem the program activity manager and the planning and budgeting coordinator is challenging.

The lack of comprehension of the planning and budgeting process is caused by the lack of education and training on planning and budgeting for each institution (Kani et all, 2012). This would weaken the Dit Kesjaor's position when dicussing the budget. Coordination also greatly influences the quality of the results of the planning and budgeting process. Lack of coordination during the planning stage would cause overlapping activities, which in turn would cause inefficiency. Invalid and outdated data is another problem (Purnamasari dan Marhaeni, 2012). Invalid and outdated data would also weaken the directorate's position, therefore there might be budget cuts.

\section{CONCLUSIONS}

Politics plays an important role in determining the size of budget allocated for the Dit Kesjaor. It greatly influences the policy making process, especially when there are conflicts, negotiations, and cooperations when determining the size of the budget allocated and the targets. What we must pay attention to are the prioritized activities, the financial capability of the country, the results of the evaluation of the previous year's activities, both the realized budget and the performance obtained, and also the government's vision and missions and quickwins.

Based on the results, discussion and conclusion above, there could be recommended as follows:

1. For the Dit Kesjaor: Issue an SK on the planning and budgeting team; Issue a Circulating Letter (SE) on a staged budget at the Dit Kesjaor; Increase the capabilities of the human resources of the planning team on the technical importance of their programs and knowledge on planning and budgeting cycles, also ability to advocate and negotiate the programs of occupational and sports health.

2. For the Sesditjen Kesmas: the Planning Bureau of the Ministry of Health, and APIP: Provide more intense technical guidance to the Dit Kesjaor; and maximalize the planning and budgeting in stages.

3. For the IX Commission (DPR): Should recruit experts on health in comprehensive to provide more positive inputs for the members.

4. For the Ministry of Finance and the Bappenas: Recommended to improve comprehension on the main tasks and functions of the Dit Kesjaor; and the importance of maintaining good relations with other institutions.

5. For other researchers: To perform further research on the political aspects of planning and budgeting in larger units or institutions, such as the ministry of health; Perform further research on the involvement of political parties in planning and budgeting policy making.

\section{REFERENCES}

Abdullah, Syukriy (2004). Perilaku Oportunistik legislatif.

Downloaded

from

https://swamandiri.wordpress.com/2008/02/10/perilaku-

oportunistik-legislatif-dalam-penganggaran-daerah-bukti-

empiris-atas-aplikasi-agency-theory-di-sektor-publik/comment-

page-1/ accessed on 20 Februari 2016

Andersen, Asger Lau., \& Lassen, David Dreyer. (2010). Fiscal

Governance and Electoral Accountability: Evidence from Late

Budgets. Departement of Economics, University of Copenhagen

Ayuningtyas, Dumilah (2008). Kotak Hitam Sistem Penetapan Kebijakan Dan Faktor yang Mempengaruhinya. Jurnal Manajemen Pelayanan Kesehatan; Vol 11, hal. 44 - 48

BPS (2015). Keadaan Pekerja di Indonesia 2015. Downloaded from https://www.bps.go.id/index.php/publikasi/1021 accessed on 20 Februari 2016

Chen, Bradley, dan Cammet, Melani (2012). Informal Politics and inequity of Acces to Healthcare in Lebanon. International Journal for equity in Health, $11: 23$

Hasanbasri, Mubasysyir, (2007). Pendekatan Sistem Dalam Perencanaan Program Daerah. Jurnal Manajemen Pelayanan Kesehatan; Vol 10, hal. $58-63$

Kani, Abdul, Marhaeni Dewi, et al. (2012). Evaluasi Perencanaan dan Penganggaran Dinas Kesehatan Kabupaten Pessisir Selatan Provinsi Sumatera Barat. Jurnal Manajemen Pelayanan Kesehatan; Vol 15, hal. 131 - 139

Kickbusch, Ilona (2015). Politics or Technocracy -What Next For Global Health? International Journal of Health Policy and Management. Vol. 5(3), Pg. 201-204

Mackenbach, Johan P (2014). Political Determinants of health. European Journal of Public Health, Vol. 24 No. 1, 2.

Marhaeni, Dewi, dan Herawati, Diah (2008). Intervensi Politik Dalam Proses Penganggaran Departemen Kesehatan Tahun 2006-2007. Jurnal Manajemen Pelayanan Kesehatan; Vol 11, hal. $173-178$

Moleong, J. Lexy (2007). Metodologi Penelitian Kualitatif Edisi 
Revisi. Rosda, Jakarta

Navarro, Vicente; Muntaner, Carles; Borrel, Carme; Benach, Joan; Et al (2006). Politics and health outcomes. The Lancet; Sep 16-Sep 22; 368, 9540; ProQuest Pg. 1033

Norton, Andy \& Elson, Diane (2002). What's behind the budget? Politics, rights and accountability in the budget process. Overseas Development Institute

Purnamasari, Wini, dan Marhaeni Dewi (2012). Faktor-Faktor yang mempengaruhi Perencanaan Penganggaran Kesehatan Bersumber APBD : Sebuah Tinjauan Literatur. Program Pascasarjana Universitas Padjajaran: Bandung.

Saputra, Wiko. (2014). APBN Konstitusi Bidang Kesehatan dan Jaminan Sosial Kesehatan 2014. Jakarta

Seputar APBN. Anggaran Kesehatan 2011-2015. Downloaded from http://www.anggaran.depkeu.go.id/dja/athumbs/apbn/kesehatan APBNP2015.pdf accessed on 17 Februari 2016

Wahyu Kartiko, Sigit (2011). Pengaruh Ketidakmayoritasan Partai Politik Kepala Daerah Dalam DPRD (Divided Government) Terhadap Keterlambatan Penetapan APBD (Budget Delay) Berdasarkan Perspektif Ekonomi Politik. Depok : FE UI

Wildavsky, A. (1992). Political Implication of Budget Reform: A Retrospective. Public Administration Review, Vol. 52, No. 6 